\title{
Bradykinin-activated Membrane-associated Phospholipase C in Madin-Darby Canine Kidney Cells
}

\author{
Didier Portilla, Jeremiah Morrissey, and Aubrey R. Morrison \\ Departments of Internal Medicine and Pharmacology, Washington University School of Medicine, St. Louis, Missouri 63110
}

\begin{abstract}
Previous studies have demonstrated that bradykinin stimulates the rapid release of inositol $1,4,5$ trisphosphate $\left(\mathrm{IP}_{3}\right)$ from membrane phosphatidylinositol 4,5 bisphosphate $\left(\mathrm{PIP}_{2}\right)$ in Madin-Darby canine kidney (MDCK) cells. Since current evidence would suggest that the activation of phospholipase $C$ (PLC) is mediated through a guanine nucleotide-binding protein in receptor-mediated activation of PLC, we evaluated the role of guanine nucleotide proteins in receptor-mediated (bradykinin-stimulated) activation of PLC in MDCK cells. Bradykinin at $10^{-7} \mathrm{M}$ produced a marked increase in $\mathrm{IP}_{\mathbf{3}}$ formation within $10 \mathrm{~s}$ increasing from a basal level of 46.2 to 686.6 $\mathrm{pmol} / \mathrm{mg}$ cell protein, a 15 -fold increase. Pretreatment of MDCK cells in culture with $200 \mathrm{ng} / \mathrm{ml}$ of pertussis toxin for 4 $h$ reduced the bradykinin-stimulated response to $205.8 \mathrm{pmol} /$ mg protein. A 41-kD protein substrate in MDCK membranes was ADP ribosylated in vitro in the presence of pertussis toxin. The ADP ribosylation in vitro was inhibited by pretreatment of the cells in culture with pertussis toxin. Membranes from MDCK cells incubated in the presence of $\left[{ }^{3} \mathbf{H}\right] \mathrm{PIP}_{2} /$ phosphatidyl ethanolamine liposomes demonstrated hydrolysis of $\left.{ }^{3} \mathrm{H}\right] \mathrm{PIP}_{2}$ with release of $\left.{ }^{3}{ }^{3} \mathrm{H}\right] \mathrm{IP}_{3}$ when GTP $100 \mu \mathrm{M}$ or GTP $\gamma \mathrm{S}$ $10 \mu \mathrm{M}$ was added. Bradykinin $10^{-7} \mathrm{M}$ added with GTP 100 $\mu \mathrm{M}$ markedly increased the rate of hydrolysis within $10 \mathrm{~s}$, thus demonstrating a similar time course of PLC activation as intact cells. These results demonstrate that bradykinin binds to its receptor and activates a membrane-associated PLC through a pertussis toxin-sensitive, guanine nucleotide protein.
\end{abstract}

\section{Introduction}

The hydrolysis of membrane-associated phosphatidylinositol 4,5 bisphosphate $\left(\mathrm{PIP}_{2}\right)^{1}$ to water-soluble inositol $1,4,5$ trisphosphate $\left(\mathrm{IP}_{3}\right)$ can be demonstrated in many cell systems in response to a wide variety of agonists (1-7). In rabbit papillary collecting tubule cells (RPCT) in culture, exposure to bradykinin (BK) initiates the hydrolysis of $\mathrm{PIP}_{2}$ by phospholipase $\mathrm{C}$

\section{Address reprint request to Dr. Morrison. \\ Received for publication 9 July 1987 and in revised form 30 De- cember 1987.}

1. Abbreviations used in this paper: BK, bradykinin, G, guanine nucleotide-binding protein; $\mathrm{Gi}$, inhibitory guanine nucleotide binding protein; IAP, islet-activating protein; $\mathrm{IP}_{3}$, inositol 1,4,5 trisphosphate; MDCK, Madin-Darby canine kidney (cells); PIP $_{2}$ phosphatidylinositol 4,5 bisphosphate; RPCI, renal papillary collecting tubule (cells); TFA, trifluoroacetyl.

J. Clin. Invest.

(c) The American Society for Clinical Investigation, Inc. 0021-9738/88/06/1896/07 \$2.00

Volume 81, June 1988, 1896-1902 with rapid formation of inositol 1,4,5 trisphosphate, calcium mobilization, and $\mathrm{PGE}_{2}$ production $(8,9)$ with an $\mathrm{ED}_{50}$ of $\sim 10^{-8} \mathrm{M}$ BK for all three responses.

Madin-Darby canine kidney (MDCK) cells assumed to be of distal tubular or cortical collecting duct origin (10-15) also respond to $\mathrm{BK}$ with a rapid increase in $\mathrm{IP}_{3}$ production in sufficient amount to account for the observed intracellular calcium mobilization $(16,17)$. In these cells the hydrolysis of PIP $_{2}$ can also be explained by activation of a phospholipase $\mathrm{C}$ initiated by the kinin. Two types of phospholipase $C$ enzymes have been described. A membrane-bound form $(18,19)$ that is coupled to receptors and is phosphoinositide specific and activated by membrane guanine nucleotide-binding protein, and, a soluble enzyme isolated from human platelets and calf brain (20-26), which is also activated by guanine nucleotides, is calcium dependent and relatively specific for polyphosphoinositides.

Currently, there is strong evidence from studies in many tissues that receptor coupling to phospholipase $\mathrm{C}$ is mediated by a guanine nucleotide (GTP)-binding protein (G) (27-34). To study the role of these GTP-binding proteins, islet-activating protein (IAP) (pertussis toxin), which produces ADP ribosylation of the $\alpha$-subunit of $\mathrm{Gi}$ and inactivates its biological activity, has been extensively utilized. In neutrophils (35-42), mast cells (43), and human leukemic cells HL-60 (44, 45), chemotactic peptide-induced PIP $_{2}$ hydrolysis and IP $_{3}$ formation, calcium mobilization, and arachidonic acid release were greatly inhibited by pretreatment of the cells with pertussis toxin. This suggests that a pertussis toxin substrate couples the receptor for f-Met-Leu-Phe, to phospholipase C.

Whether the GTP-binding protein that interacts with phospholipase $\mathrm{C}$ is identical with $\mathrm{Gi}(41)$ has not been ascertained. In neutrophils, pretreatment with pertussis toxin is associated with ADP ribosylation of a single membrane-bound protein (relative molecular mass $41 \mathrm{kD}$ ) characterized as the $\alpha$-subunit of $\mathrm{Gi}$. When $\mathrm{Gi}$ (isolated from brain) was added to pertussis toxin-pretreated membranes, f-Met-Leu-Phe-binding affinity and GTPase activity were restored (46).

Previous studies from our laboratory in RPCT demonstrate that pretreatment with $\mathrm{IAP}$ inhibits $\mathrm{IP}_{\mathbf{3}}$ labeling, calcium mobilization, and $\mathrm{PGE}_{2}$ production after stimulation with $\mathrm{BK}$.

We designed the present studies to determine whether BKstimulated $\mathrm{PIP}_{2}$ hydrolysis and $\mathrm{IP}_{3}$ formation in MDCK cells were influenced by pertussis toxin pretreatment and to test the hypothesis that in an in vitro system of MDCK plasma membranes, the $\mathrm{BK}$ receptor is coupled to a membrane-bound $\mathrm{PIP}_{2}$ phospholipase $\mathrm{C}$ through a GTP-binding protein.

\section{Methods}

Materials. D-myo[2- $\left.{ }^{3} \mathrm{H}\right]$ Inositol-1-phosphate, D-myo[2- $\left.{ }^{3} \mathrm{H}\right]$ inositol 1,4 bisphosphate, and D-myo[2- $\left.{ }^{3} \mathrm{H}\right]$ inositol 1,4,5 trisphosphate $\left(\mathrm{IP}_{3}\right)$ were obtained from Amersham Corp., Arlington Heights, IL. $\left[{ }^{3} \mathrm{H}\right]$ phosphatidylinositol 4,5 bisphosphate $\left(\mathrm{PIP}_{2}\right)$ and $\left[\alpha-{ }^{32} \mathrm{P}\right] \mathrm{NAD}$ were 
obtained from New England Nuclear, Boston, MA. IAP was purchased from List Biochemical, Campbell, CA. Bradykinin (BK), phosphatidyl ethanolamine (PE), PIP ${ }_{2}$, GTP, GTP $\gamma$ S, alkaline phosphatase, and cel culture additives were all purchased from Sigma Chemical Company, St. Louis, MO. MDCK cells were obtained from American Type Culture Collection, Rockville, MD.

Cell culture and $I P_{3}$ isolation. MDCK cells were maintained in culture as previously described (10). For the current studies, cells were grown to confluency in $25-\mathrm{cm}^{2}$ culture flasks for $48 \mathrm{~h}$ in serum-free media and preincubated in the presence and absence of IAP (200 $\mathrm{ng} / \mathrm{ml}$ ) for $4 \mathrm{~h}$ before stimulation with BK $10^{-7} \mathrm{M}$. Under these conditions pertussis toxin produced a 70\% inhibition of $\mathrm{IP}_{3}$ labeling, calcium mobilization, and $\mathrm{PGE}_{2}$ production in RPCT in culture (data not presented). The reaction was terminated after 10 or $60 \mathrm{~s}$ by addition of $5 \%$ perchloric acid to a final concentration of $2.5 \%$ perchloric acid. Cells were then scraped from the flask, the suspension was centrifuged, and the pellet was assayed for protein (47). The supernatant was adjusted to $\mathrm{pH} 6$ with a saturated solution of potassium bicarbonate and spiked with $\left[{ }^{3} \mathrm{H}\right] \mathrm{IP}_{3}$ to monitor recovery and retention volume. Samples were then applied to 0.3-ml amino columns (Supelco, Bellefonte, PA) washed with $\mathrm{H}_{2} \mathrm{O}$, and the inositol polyphosphates were eluted with $600 \mu \mathrm{l}$ of $1.5 \mathrm{M}$ ammonium hydroxide. $\mathrm{IP}_{3}$ was then isolated by HPLC. Chromatography was performed on a Pharmacia Mono Q HR $5 / 5$ anion exchange column (Pharmacia Fine Chemicals, Piscataway, NJ) using two Waters $6000 \mathrm{~A}$ pumps and U6K injector (Waters Instruments, Rochester, $\mathrm{MN}$ ). The mobile phase consisted of $10 \mathrm{mM}$ Tris base, pH 8.5 (buffer A) and $500 \mathrm{mM}$ sodium sulfate in buffer A (48). The gradient was increased linearly from 25 to $150 \mathrm{mM}$ sodium sulfate over $25 \mathrm{~min}$. Samples coeluting with authentic $\left[{ }^{3} \mathrm{H}\right] \mathrm{IP}_{3}$ were collected, alkaline phosphatase $(25 \mathrm{U} / \mathrm{ml})$ was added, and fractions were incubated at $37^{\circ} \mathrm{C}$ for $3 \mathrm{~h}$ to remove phosphate groups. The inositol released was measured by negative ion chemical ionization mass spectrometry as previously described (16). Briefly, samples were spiked with $20 \mathrm{ng}$ of hexadeuterated inositol before alkaline phosphatase hydrolysis and then desalted on Bio Rex MSZ 501 mixed bed resin (Bio-Rad Laboratories, Richmond, CA) and lyophilized. The lyophilized samples were converted to the hexatrifluoroacetyl (TFA) derivatives and introduced into the gas chromatography in derivatizing reagent. The inositol mass was calculated from the ratio between $\mathrm{m} / \mathrm{z}$ 642, ion-monitored for TFA d0-inositol, and $\mathrm{m} / \mathrm{z} 647$, ion-monitored for TFA d6-inositol.

Determination of pertussis toxin substrate. ADP ribosylation of proteins in cell membranes was determined by measuring the $\left[{ }^{32} \mathrm{P}\right]-$ NAD incorporation catalyzed by pertussis toxin in vitro (43). MDCK cells incubated in the presence and absence of IAP $(200 \mathrm{ng} / \mathrm{ml})$ for $2 \mathrm{~h}$ were suspended in ice-cold buffer consisting of Tris $\mathrm{HCl} 25 \mathrm{mM}, \mathrm{pH}$ 7.4; EDTA $1 \mathrm{mM}$; dithiothreitol $1 \mathrm{mM}$; and aprotinin $100 \mathrm{U} / \mathrm{ml}$. Cellular homogenates were prepared with a Dounce homogenizer (five strokes) and pelleted by centrifugation at $100,000 \mathrm{~g}$ for $30 \mathrm{~min}$. The membrane pellet was incubated in a final volume of $100 \mu l$ at $30^{\circ}$ for $30 \mathrm{~min}$ in buffer containing $100 \mathrm{mM}$ potassium phosphate, $\mathrm{pH} 7.5 ; 5$ $\mathrm{mM}$ magnesium chloride; $2 \mathrm{mM}$ ATP; $20 \mathrm{mM}$ thymidine; $10 \mu \mathrm{M}$ [ $\left.{ }^{32} \mathrm{P}\right] N A D$; and $10 \mu \mathrm{g}$ of cholera or pertussis toxin. A control in the absence of toxin was run in parallel. The reaction was terminated with $10 \%$ TCA, and the protein was precipitated, collected by centrifugation, and washed with diethylether to remove the TCA. The protein precipitate was dissolved in SDS sample buffer and the proteins separated by molecular mass on an $11 \%$ polyacrylamide SDS-containing gel by method of Laemmli (49). The gels were then stained, destained, dried, and autoradiographed.

Preparation of MDCK plasma membranes and membrane vesicles. MDCK cells were grown to confluency in $75-\mathrm{cm}^{2}$ culture flasks and plasma membranes were prepared as previously described for fibroblasts (50). The monolayers were washed twice with calcium- and magnesium-free phosphate buffer and rinsed once with a $20 \mathrm{mM}$ Tris maleate buffer containing $0.5 \mathrm{mM}$ EGTA and $0.5 \mathrm{mM}$ EDTA. Cells were then scraped with a rubber policeman into Tris buffer and disrupted by Dounce homogenization ( 50 strokes). The broken cell preparation was centrifuged at $500 \mathrm{~g}$ for $5 \mathrm{~min}$ to remove nuclei and unbroken cells. The supernatant was centrifuged at $11,000 \mathrm{~g}$ for 15 min and the pellet was enriched in plasma membranes was resuspended in Tris buffer.

Liposomes were prepared by mixing $40 \mathrm{nmol} \mathrm{PIP}, 400 \mathrm{nmol} P E$, and $3 \times 10^{6} \mathrm{cpm}\left[{ }^{3} \mathrm{H}\right] \mathrm{PIP}_{2}$ in $\mathrm{CHCl}_{3}: \mathrm{MeOH}(2: 1)$ and then evaporated under nitrogen. $20 \mathrm{mM}$ Tris maleate, $\mathrm{pH} 7.4$, was then added to yield 1 nmol $\left[{ }^{3} \mathrm{H}\right] \mathrm{PIP}_{2}$ with $10 \mathrm{nmol} \mathrm{PE}$ per $40-\mu \mathrm{l}$ aliquot and sonicated for 5 min at room temperature.

Assay of phospholipase $C$ activity. Membrane-associated phospholipase $C$ activity was determined by measuring the amount of $\left[{ }^{3} \mathrm{H}\right] \mathrm{IP}_{3}$ produced from $\left[{ }^{3} \mathrm{H}\right] \mathrm{PIP}_{2}$ added as exogenous substrate. The reaction was carried out in tubes containing membrane protein $(50 \mu \mathrm{g}), 20 \mathrm{mM}$ Tris maleate, $\mathrm{pH} 7.4 ; 100 \mathrm{nM}$ free calcium (adjusted with $\mathrm{Ca}^{2+} / \mathrm{EGTA}$ buffer); and in the presence or absence of GTP $100 \mu \mathrm{M}, \mathrm{GTP} \gamma \mathrm{S} 10 \mu \mathrm{M}$ and $\mathrm{BK} 10^{-7} \mathrm{M}$. The reaction was initiated by addition of $50 \mu \mathrm{l}$ of the plasma membranes to the labeled liposomes in a final volume of 100 $\mu \mathrm{l}$. The reaction was carried out at $37^{\circ} \mathrm{C}$ for 10 and $60 \mathrm{~s}$ of incubation and terminated by the addition of ice-cold $\mathrm{CHCl}_{3}, \mathrm{MeOH}, \mathrm{H}_{2} \mathrm{O}$ (1:2:1). $\left[{ }^{3} \mathrm{H}\right] \mathrm{IP}_{3}$ was isolated by HPLC as previously described except that the buffer used as the mobile phase was changed to $20 \mathrm{mM}$ ethanolamine, $\mathrm{pH} 9.5$, and counted by liquid scintillation spectrometry. An aliquot of the membrane preparation was removed for protein determination. Similar experiments were carried out in presence of varying concentrations of GTP and $\mathrm{Ca}^{2+}$.

\section{Results}

The HPLC anion exchange system of separation of the polyphosphoinositides used in the present study is depicted in Fig. 1. This allowed us to isolate the inositol $1,4,5$ trisphosphate

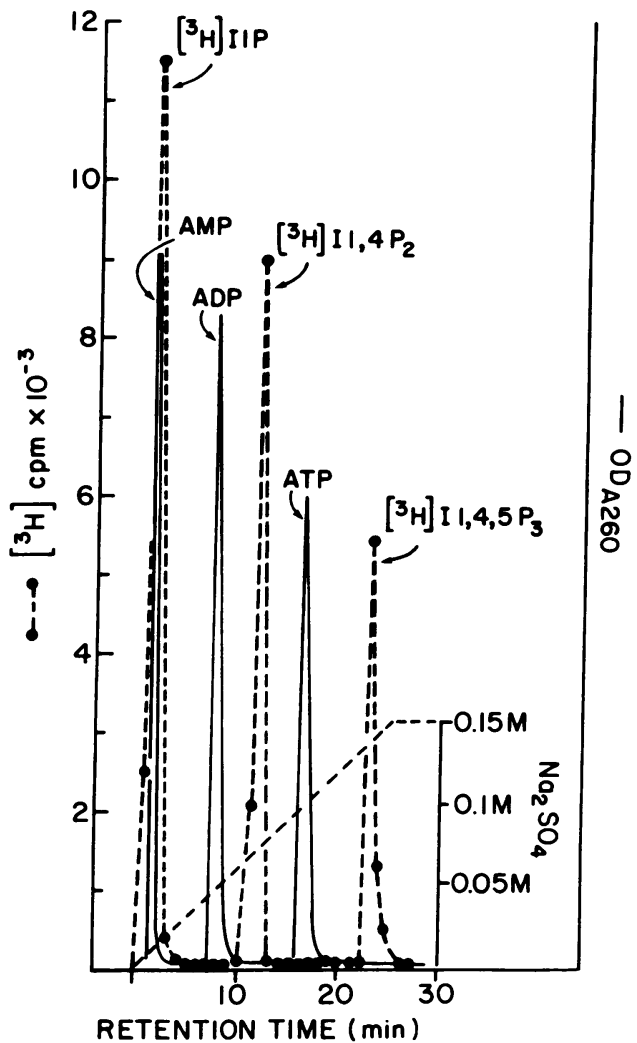

Figure 1. HPLC separation of inositol polyphosphates. The retention times for the inositol phosphates were: $\mathrm{IP}_{1}, 2 \mathrm{~min} ; \mathrm{I1}, 4 \mathrm{P}_{2}, 12 \mathrm{~min}$; I $1,4,5 \mathrm{P}_{3}, 24 \mathrm{~min}$. 
isomer away from the $1,3,4$ isomer, which migrated ahead of the 1,4,5 isomer, and also to perform alkaline phosphatase hydrolysis of the phosphate groups. We also observed as in platelets (51) that samples prepared from acid digests of $\mathrm{IP}_{3}$ yielded threefold higher basal values (unstimulated cells) of inositol that did those from alkaline phosphatase digested samples. This could possibly be explained by the greater selectivity of alkaline phosphatase for phosphomonoester linkages. The nucleotides AMP, ADP, ATP were also separated in this system from $\mathrm{IP}_{3}$.

The initial experiments were designed to evaluate the effect of IAP in the formation of intracellular $\mathrm{IP}_{3}$. After $4 \mathrm{~h}$ of incubation, MDCK monolayers were washed three times with Krebs buffer and stimulated with BK $10^{-7} \mathrm{M}$. BK $10^{-7} \mathrm{M}$ produced a marked increase in $\mathrm{IP}_{3}$ formation within $10 \mathrm{~s}$ from a basal level of 46.2 to $686.6 \mathrm{pmol} / \mathrm{mg}$ protein. Pretreatment with IAP ( $200 \mathrm{ng} / \mathrm{ml}$ for $4 \mathrm{~h}$ ) reduced this stimulation to 205.8 $\mathrm{pmol} / \mathrm{mg}$ protein $(n=5)$ (Fig. 2). The increase in $\mathrm{IP}_{3}$ formation in response to BK was significant at the $P<0.01$ level, and the IAP-treated level was significantly different from BK alone at $P<0.01$ level and from basal level at $P<0.05$ level. Larger doses of IAP do not reduce this level completely to basal and the maximum inhibition in our hands was $75 \%$. The experiments carried out in intact MDCK cells demonstrated a marked stimulation of $\mathrm{PIP}_{2}$ hydrolysis after bradykinin stimulation with a 15-fold increase in the intracellular $\mathrm{IP}_{3}$. The difference between this study and our earlier study (16) is in the basal level of $\mathrm{IP}_{3}$. The current HPLC system while it does not totally resolve $1,3,4 \mathrm{IP}_{3}$ from $1,4,5 \mathrm{IP}_{3}$ is much better than our previous HPLC system, which did not separate the two isomers. Thus the basal level was significantly influenced by a contribution from the $1,3,4 \mathrm{IP}_{3}$ isomer. The experiments also demonstrated that the increase in $\mathrm{PIP}_{2}$ hydrolysis with $\mathrm{BK}$ stimulation was dependent on an intact GTP-binding protein which was inhibitable by pertusis toxin.

$I A P$-catalyzed ADP ribosylation of MDCK membrane protein. ADP ribosylation of MDCK membranes was carried out with $\left[\alpha-{ }^{32} \mathrm{P}\right] \mathrm{NAD}$. The ${ }^{32} \mathrm{P}$ content of the membrane protein fractions was then analyzed by SDS/polyacrylamide gel electrophoresis. As shown in Fig. 3, a protein of $M_{\mathrm{r}} 41 \mathrm{kD}$ was labeled in vitro only when IAP was present in the reaction mixture. We could completely inhibit the ADP ribosylation in vitro by pretreatment of cells IAP. This fact coupled with the observation that we could maximally inhibit BK-stimulated $\mathrm{IP}_{3}$ formation by $75 \%$ might suggest there was another $\mathrm{G}$ pro-

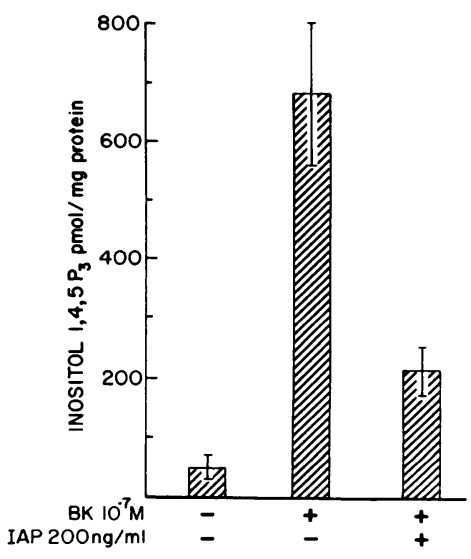

Figure 2. Inhibition of BKstimulated $\mathrm{IP}_{3}$ formation with IAP. MDCK cells were incubated in media alone or preincubated with IAP for $4 \mathrm{~h}$. This represents the mean of duplicate determinations from five separate experiments.

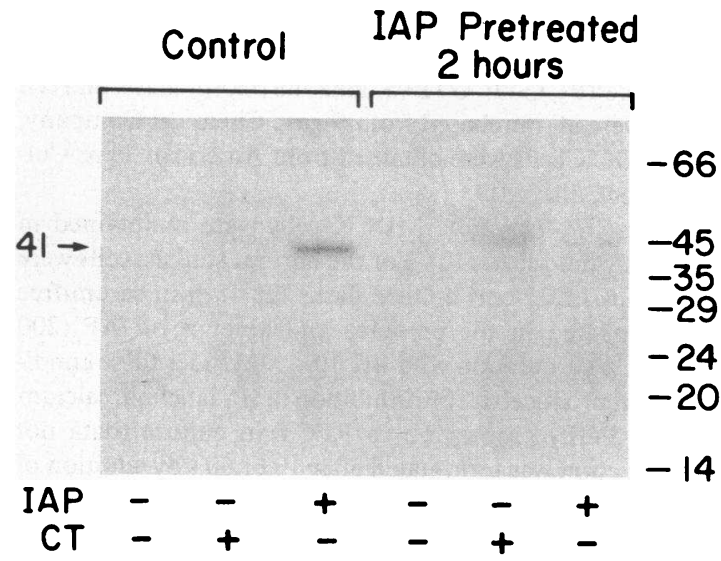

Figure 3. ADP ribosylation of a 41-kD protein in MDCK membranes by pertussis toxin. Membranes from MDCK cells were prepared from cells that were incubated in the presence or absence (control) of IAP $200 \mathrm{ng} / \mathrm{ml}$ for $2 \mathrm{~h}$. MDCK membranes were then incubated with $\left[\alpha-{ }^{32} \mathrm{P}\right] N A D$ in the presence or absence of cholera toxin $(C T)$ and pertussis toxin (IAP) as described in Methods. $M_{\mathrm{r}}$ markers given in kilodaltons.

tein involved which was not pertussis toxin sensitive. When IAP was replaced by cholera toxin in the incubation mixture, another protein with $M_{\mathrm{r}}$ of $45 \mathrm{kD}$ was also ADP ribosylated though less intensely than the $41-\mathrm{kD}$ protein with IAP. When MDCK membranes were prepared from IAP-pretreated cells in culture, the IAP-induced ${ }^{32} \mathrm{P}$ labeling of the $M_{\mathrm{r}} 41-\mathrm{kD}$ protein was significantly decreased. These results suggest that IAP catalyzes transfer of the ADP ribose moiety of NAD to a 41-kD protein of MDCK cell membranes.

Phospholipase $\mathrm{C}$ activity in MDCK membranes was assayed by fixing the calcium concentration to $100 \mathrm{nM}$ utilizing an $\mathrm{EGTA}^{+} / \mathrm{Ca}^{+2}$ buffer at a pH of 7.4. The amount of $\left[{ }^{3} \mathrm{H}\right] \mathrm{IP}_{3}$ formed after incubation with exogenous $\left[{ }^{3} \mathrm{H}\right] \mathrm{PIP}_{2} / \mathrm{PE}$ liposomes was estimated after extraction from the membranes, HPLC separation as before, and liquid scintillation spectrometry.

Under these conditions, BK $10^{-7} \mathrm{M}$ stimulated $\left[{ }^{3} \mathrm{H}\right] \mathrm{IP}_{3}$ production 10-fold. Addition of $100 \mu \mathrm{M}$ GTP stimulated $\mathrm{IP}_{3}$ release 12-fold. However, the addition of $\mathrm{BK}$ potentiated the production of $\left[{ }^{3} \mathrm{H}\right] \mathrm{IP}_{3}$ by GTP alone $(3,376 \mathrm{vs} .1,210 \mathrm{cpm} / \mathrm{mg}$ membrane protein), an effect which was significantly different at $10 \mathrm{~s}$ but not $60 \mathrm{~s}$ (Fig. 4). Similar observations were seen by substituting GTP $\gamma \mathrm{S}$ for GTP (data not shown). The significant stimulation of $\mathrm{IP}_{3}$ formation seen at $10 \mathrm{~s}$ of incubation with $\mathrm{BK}$ alone could be due to the presence of small amounts of GTP in our membrane preparation. Fig. 5 illustrates the time course of hydrolysis of exogenous $\left[{ }^{3} \mathrm{H}\right] \mathrm{PIP}_{2}$. As previously observed, the stimulation of $\mathrm{IP}_{3}$ formation in response to BK and GTP is rapid and detected as early as $10 \mathrm{~s}$. The dose dependency of this response to the concentration of GTP in the incubation is shown in Fig. 6. In these experiments we could show that GTP was converted to GDP by monitoring the elution off the ion exchange column at $260 \mathrm{~nm}$. Thus there appears to be GTPase activity in our membrane preparations. However, since we are not dealing with the purified G-protein, we cannot conclude on the basis of our experiments if the GTPase activity resides in the $G$ protein itself or is due to other GTPases in the membrane. In addition, we were only able to 

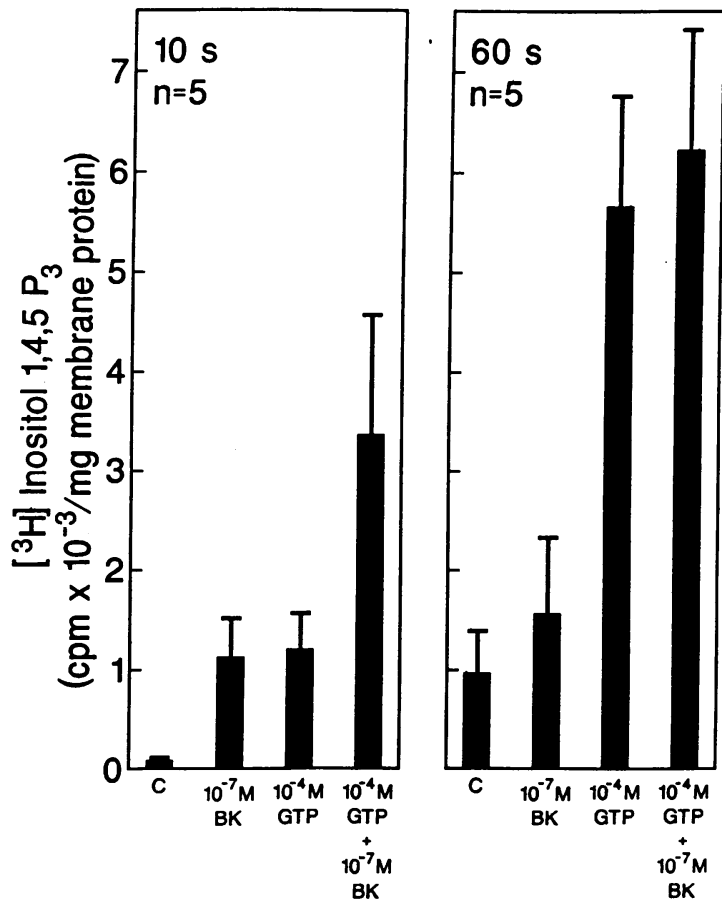

Figure 4. $\left[{ }^{3} \mathrm{H}\right] \mathrm{IP}_{3}$ formed in response to guanine nucleotides and $\mathrm{BK}$. MDCK membranes were incubated with $\left[{ }^{3} \mathrm{H}\right] \mathrm{PIP}_{2}: \mathrm{PE}$ liposomes for the indicated times in the presence of a free calcium concentration of $100 \mathrm{nM}\left(\mathrm{EGTA} / \mathrm{Ca}^{2+}\right.$ buffer) under control conditions, $C$; with $\mathrm{BK}$ $10^{-7} \mathrm{M}$; GTP $100 \mu \mathrm{M}$ alone; or GTP $100 \mu \mathrm{M}$ and BK $10^{-7} \mathrm{M}$. Results are expressed as cpm of $\left[{ }^{3} \mathrm{H}\right] \mathrm{IP}_{3}$ per mg protein from five different experiments.

demonstrate an increase in $\mathrm{BK}$-induced $\left[{ }^{3} \mathrm{H}\right] \mathrm{PIP}_{2}$ hydrolysis over and above that of GTP alone at low $\mathrm{Ca}^{2+}$ concentration (Fig. 7). At $0 \mathrm{Ca}^{2+}$ no hydrolysis was observed and at $2 \mu \mathrm{M}$ $\mathrm{Ca}^{2+}$ BK caused no hydrolysis over and above that produced by GTP alone. These observations are similar to the observation by Magnaldo et al. (50). When MDCK membranes were prepared from pertussis toxin-treated cells the stimulation of GTP plus bradykinin was inhibited at $10 \mathrm{~s}$ of incubation (Fig. 8) and this inhibition persisted at $60 \mathrm{~s}$ (data not shown). These results in MDCK cell membranes are consistent with the observations in intact MDCK cells where BK stimulates a very rapid hydrolysis of $\mathrm{PIP}_{2}$ with formation of $\mathrm{IP}_{3}$ through a GTPbinding protein that couples the bradykinin receptor to a membrane-bound phospholipase $\mathrm{C}$.

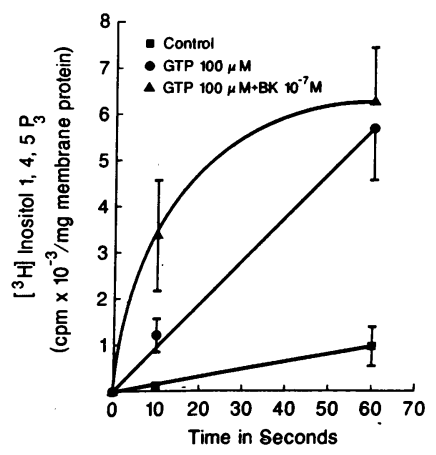

Figure 5. Time course of ${ }^{3} \mathrm{H}$ $\mathrm{IP}_{3}$ formation. Membranes from MDCK were incubated in a $100 \mathrm{~nm}$ free $\mathrm{Ca}^{2+}$ buffer under control conditions; in the presence of GTP $100 \mu \mathrm{M}$ (GTP), and in the presence of GTP $100 \mu \mathrm{M}$ plus BK $10^{-7} \mathrm{M}$ $(G T P+B K)$. Results are expressed as cpm of $\left[{ }^{3} \mathrm{H}\right] \mathrm{IP}_{3}$ per $\mathrm{mg}$ protein and are representative of four different experiments.

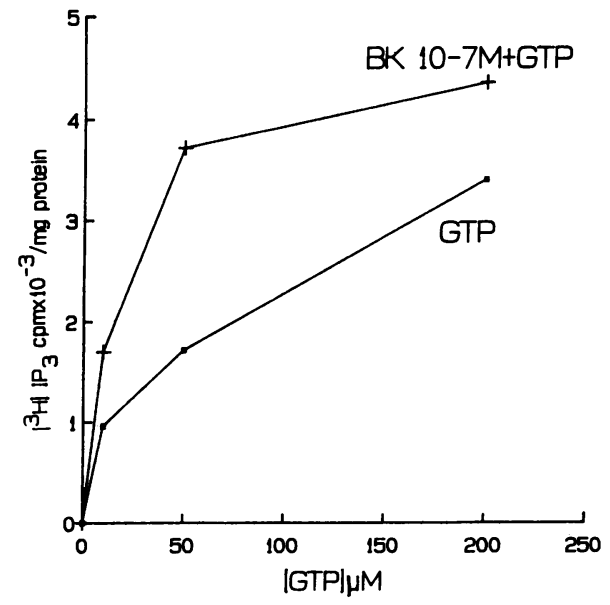

Figure 6. Dose dependency of $\left[{ }^{3} \mathrm{H}\right] \mathrm{IP}_{3}$ formation with GTP concentration.

\section{Discussion}

We report here the presence of a membrane-associated phospholipase $C$ in intact MDCK cells that in the presence of bradykinin initiates the hydrolysis of $\mathrm{PIP}_{2}$ with the rapid formation (10 s) of $I P_{3}$. This response is inhibited by pretreatment of these cells with IAP $(200 \mathrm{ng} / \mathrm{ml})$, thus suggesting a role for a guanine nucleotide protein in receptor-mediated transmembrane signaling.

Parallel studies in MDCK membranes showed that in the presence of $100 \mathrm{nM}$ free $\mathrm{Ca}^{2+}$ concentration, mimicking the physiological $\mathrm{Ca}^{+2}$ concentration in unstimulated cells, guanine nucleotides (GTP or GTP $\gamma$ S) stimulated PIP ${ }_{2}$-phospholipase $\mathrm{C}$ activity with the rapid formation of $\left[{ }^{3} \mathrm{H}\right] \mathrm{IP}_{3}$ as early as $10 \mathrm{~s}$ of incubation, but the addition of $\mathrm{BK} 10^{-7} \mathrm{M}$ potentiated GTP-facilitated $\mathrm{IP}_{3}$ formation. Pretreatment of intact MDCK cells before the membrane preparation abolished both guanine nucleotide and agonist stimulation of $\left[{ }^{3} \mathrm{H}\right] \mathrm{IP}_{3}$ formation over the 60-s time course of our experiment. These results are consistent with the results obtained in intact MDCK cells and suggest the presence of a GTP-binding protein that couples the BK receptor to the activation of a membrane-bound phospho-

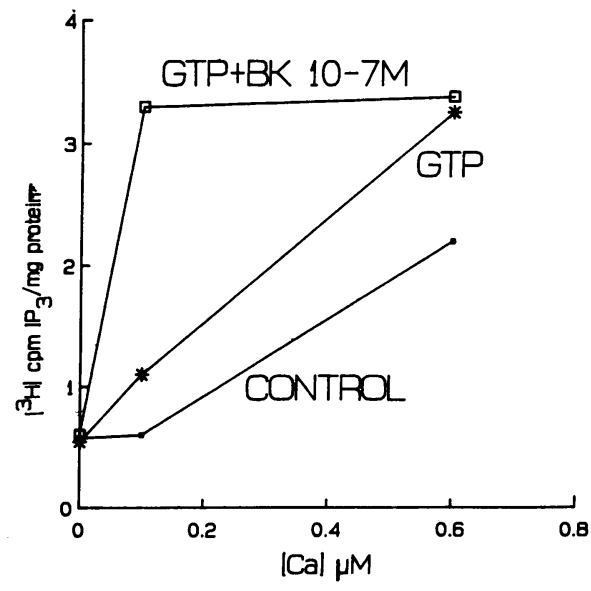

Figure 7. $\mathrm{Ca}^{2+}$ dependency of $\mathrm{BK}$-induced $\mathrm{IP}_{3}$ formation. 


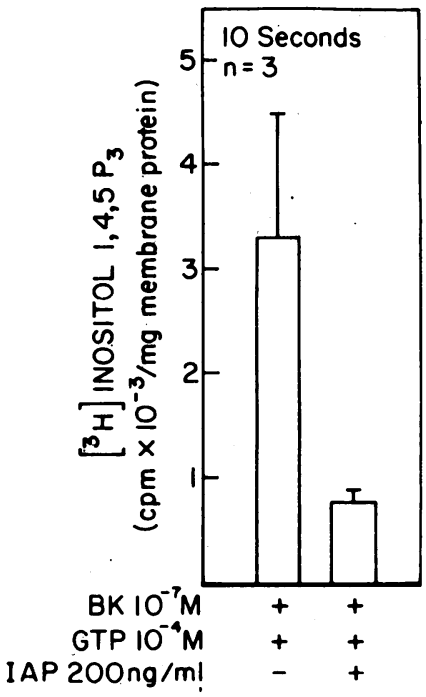

Figure 8. Inhibition of $\left[{ }^{3} \mathrm{H}\right] \mathrm{IP}_{3}$ formation with IAP. Phospholipase $C$ activity was measured in MDCK membranes as described in Methods in the presence and absence of IAP. The guanine nucleotide dependence of BK stimulation of phospholipase $\mathrm{C}$ was measured as the amount of $\left[{ }^{3} \mathrm{H}\right] \mathrm{IP}_{3}$ formed per $\mathrm{mg}$ of protein. This represents the mean of three separate experiments in duplicate. lipase C. A 41-kD pertussis toxin substrate detected by SDS polyacrylamide gel electrophoresis in our MDCK membrane preparation would suggest that this protein could be the $\alpha$-subunit of $\mathrm{Gi}$, which is ribosylated when the cells in culture are pretreated with IAP.

The role of guanine nucleotides in regulating calcium-mobilizing receptors was suggested by early studies $(28,52)$ where it was demonstrated that guanine nucleotides could promote mast cell secretion and stimulation of diacylglycerol formation from permeabilized platelets. A more direct demonstration that guanine nucleotides regulated the activity of a membrane-bound PLC comes from studies in blowfly salivary gland membranes and polymorphonuclear leukocyte membranes $(36,53-55)$. In these studies a guanine nucleotide dependency of agonist action on $\mathrm{PIP}_{2}$ breakdown was observed, and is similar to our observations in the current studies. Current available data suggest that receptor coupling to phospholipase $C$ is mediated through a GTP-binding protein. In neutrophils the G protein is ADP ribosylated and inactivated by pertussis toxin and the ribosylated subunit has a molecular mass very similar to the $\alpha$-subunit of Gi. In other cell systems as pituitary $\mathrm{GH}_{3}(56)$, pancreatic acinar (57), and liver (58), the $\mathrm{G}$ protein involved in $\mathrm{Ca}^{2+}$ mobilization appears to be insensitive to pertussis toxin treatment, suggesting that it is distinct from $\mathrm{Gi}$ or that the pertussis toxin does not penetrate the cell. Thus, at present it is not clear whether there are differences in the nature of the $G$ protein that couples receptors to phospholipase $\mathrm{C}$ in different cell types or whether there is a similar G-binding protein that differs from $\mathrm{Gi}$ in its susceptibility to ribosylation and inactivation by pertussis toxin (59). The possibility of different molecular forms of pertussis toxin-sensitive GTP-binding proteins has recently been demonstrated (60).

In these experiments we can demonstrate that the membrane preparation contains the BK receptor, the GTP-binding protein, and a membrane-associated phospholipase C. On addition of GTP to the membranes in the presence of exogenous PIP $_{2}$ substrate, GTP increases the rate of hydrolysis of the PIP $_{2}$ substrate. Furthermore, the addition of BK further stimulates the initial rate of $\mathrm{PIP}_{2}$ hydrolysis, thus demonstrating an increase in the rate of hydrolysis over and above that due to GTP alone. This difference was marked at $10 \mathrm{~s}$ with a threefold

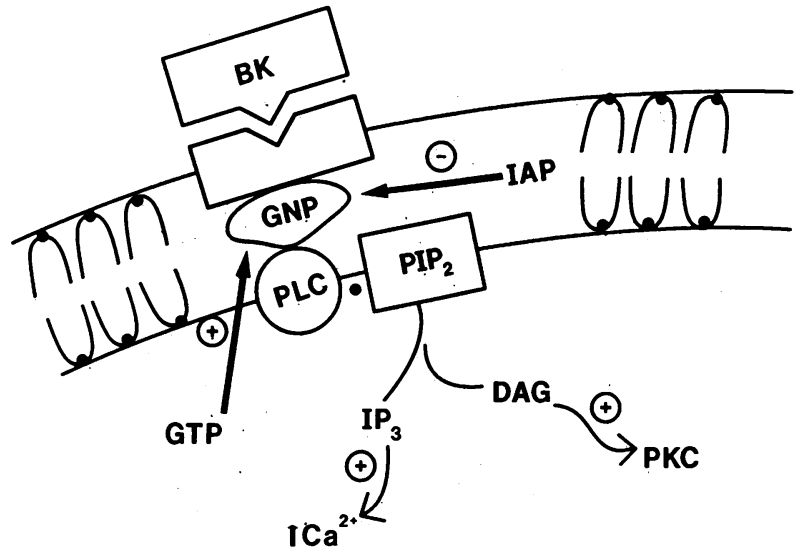

Figure 9. Model of receptor coupling to membrane-bound phospholipase C. PKC, phosphokinase C.

increase but was no longer significant at $60 \mathrm{~s}$. These observations are similar to the intact MDCK cells when BK stimulates $\mathrm{IP}_{3}$ formation at $10 \mathrm{~s}$ and is back to control by $60 \mathrm{~s}$. Previous studies in neutrophils and fibroblasts $(50,54,55)$ did not separate the different isomers for $\mathrm{IP}_{3}$, when the guanine nucleotide-dependent activation of phospholipase $C$ was studied.

Calcium-dependent stimulation of PIP $_{2}$ hydrolysis by GTP + BK was observed only at low free $\mathrm{Ca}^{2+}$ concentrations which were fixed by $\mathrm{Ca}^{2+} /$ EGTA buffers to mimic cytoplasmic calcium. This low requirement for $\mathrm{Ca}^{2+}$ in the $\mathrm{BK}$ activation of $\mathrm{PIP}_{2}$ hydrolysis by membrane phospholipase $\mathrm{C}$ is consistent with the observation that phospholipase $\mathrm{C}$ acting on $\mathrm{PIP}_{2}$ as the substrate can proceed at nanomolar $\mathrm{Ca}^{2+}$ concentrations and even in the presence of EGTA (61). This guanine nucleotide dependency of BK stimulation was clearly demonstrated under these conditions.

We propose a model of cell activation in MDCK cells (Fig. 9). Bradykinin $(B K)$ couples to the receptor through a guanine nucleotide protein $(G N P)$, with activation of a membranebound phospholipase $\mathrm{C}(P L C)$ and subsequent hydrolysis of $\mathrm{PIP}_{2}$ and rapid formation of $\mathrm{IP}_{3}$ and diacylglycerol $(D A G)$. This activation is inhibited by pertussis toxin (IAP), which causes ADP ribosylation of a $41-\mathrm{kD}$ protein similar to the $\alpha$-subunit of Gi.

\section{Acknowledgments}

This work was supported by U. S. Public Health Service Award AM-30542. Dr. Morrison is recipient of the Burroughs Wellcome Scholar Award in Clinical Pharmacology.

\section{References}

1. Berridge, M. J., and R. F. Irvine. 1984. Inositol trisphosphate, a novel second messenger in cellular signal transduction. Nature (Lond.). 312:315-321.

2. Hokin, L. E. 1985. Receptors and phosphoinositide-generated second messengers. Annu. Rev. Biochem. 54:205-235.

3. Williamson, J. R., R. H. Cooper, S. K. Joseph, and A. P. Thomas. 1985. Inositol trisphosphate and diacylglycerol as intracellular second messengers in liver. Am. J. Physiol. 248:C203-C216. 
4. Exton, J. H. 1985. Mechanisms involved in $\alpha$-adrenergic phenomena. Am. J. Physiol. 248:E633-E647.

5. Nishizuka, Y. 1984. The role of protein kinase $C$ in cell surface signal transduction and tumor promotion. Nature (Lond.). 308:693697.

6. Majerus, P. W., E. J. Neufeld, and D. B. Wilson. 1984. Production of phosphoinositide-derived messengers. Cell. 37:701-703.

7. Majerus, P. W., D. B. Wilson, T. M. Connolly, T. E. Bross, and E. J. Neufeld. 1985. Phosphoinositide turnover provides a link in stimulus-response coupling. Trends Biochem. Sci. 10:168-171.

8. Shayman, J. A., and A. R. Morrison. 1985. Bradykinin-induced changes in phosphatidyl inositol turnover in cultured rabbit papillary collecting tubule cells. J. Clin. Invest. 76:978-984.

9. Shayman, J. A., K. A. Hruska, and A. R. Morrison. 1986. Bradykinin stimulates increased intracellular calcium in papillary collecting tubules of the rabbit. Biochem. Biophys. Res. Commun. 134:299304.

10. Rindler, M. J., L. M. Chuman, L. Shaffer, and M. H. Saier. 1979. Retention of differentiated properties in an established dog kidney epithelial cell line (MDCK). J. Cell Biol. 81:635-648.

11. Cereijido, M., J. Ehrenfeld, I. Meza, and P. Martinez. 1980. Structural and functional membrane polarity in cultured monolayers of MDCK cells. J. Membr. Biol. 52:142-159.

12. Misfeldt, D. S., S. T. Hamamoto, and D. R. Pitelka. 1976. Transepithelial transport in cell culture. Proc. Natl. Acad. Sci. USA. 73:1212-1216.

13. Rindler, M. J., M. Taub, and M. H. Saier, Jr. 1979. Uptake of ${ }^{22} \mathrm{Na}$ by cultured dog kidney cells (MDCK). J. Biol. Chem. 254:11431-11439.

14. Saier, M. H., Jr. 1981. Growth and differentiated properties of a kidney epithelial cell line (MDCK). Am. J. Physiol. 240:C106-C109.

15. Hassid, A. 1981. Transport-active renal tubular epithelial cells (MDCK and $\mathrm{LLCPK}_{1}$ ) in culture. Prostaglandin biosynthesis and its regulation by peptide hormones and ionophore. Prostaglandins. 21:985-1001.

16. Portilla, D., and A. R. Morrison. 1986. Bradykinin-induced changes in inositol trisphosphate mass in MDCK cells. Biochem. Biophys. Res. Commun. 140:644-649.

17. Hassid, A., J. Gamero, D. Gamero, and N. Pidikiti. 1985 Bradykinin-evoked modulation of cytosolic $\mathrm{Ca}^{2+}$ concentrations in cultured renal epithelial (MDCK) cells. Biochem. Biophys. Res. Commun. 130:807-813.

18. Downes, C., and R. Michell. 1982. The control by $\mathrm{Ca}^{2+}$ of the polyphosphoinositide phosphodiesterase and the $\mathrm{Ca}^{2+}$ pump ATPase in human erythrocytes. Biochem. J. 202:53-58.

19. Cockcroft, S., J. M. Baldwin, and D. Allan. 1984. The Ca ${ }^{2+}$-activated polyphosphoinositide phosphodiesterase of human and rabbit neutrophil membranes. Biochem. J. 221:477-482.

20. Irvine, R. F., and R. M. C. Dawson. 1978. The distribution of calcium-dependent phosphatidylinositol specific phosphodiesterase in rat brain. J. Neurochem. 31:1427-1434.

21. Hofmann, S. L., and P. W. Majerus. 1982. Identification and properties of two distinct phosphatidylinositol-specific phospholipase C enzymes from sheep seminal vesicular glands. J. Biol. Chem. 257:6461-6469.

22. Deckmyn, H., S. M. Tu, and P. W. Majerus. 1986. Guanine nucleotides stimulate soluble phosphoinositide-specific phospholipase C in the absence of membranes. J. Biol. Chem. 261:16553-16558.

23. Low, G. M., R. C. Carroll, and W. B. Weglicki. 1984. Multiple forms of phosphoinositide specific phospholipase $C$ of different relative molecular masses in animal tissues. Biochem. J. 221:813-820.

24. Low, G. M., and W. B. Weglicki. 1983. Resolution of myocardial phospholipase $\mathrm{C}$ into several forms with distinct properties. Biochem. J. 215:325-334.

25. Hirasawa, K., R. F. Irvine, and R. M. C. Dawson. 1982. Proteolytic activation can produce a phosphatidylinositol phosphodiesterase highly sensitive to $\mathrm{Ca}^{2+}$. Biochem. J. 206:675-678.
26. Banno, Y., S. Nakashima, and Y. Nozawa. 1986. Partial purification of phosphoinositide phospholipase $\mathrm{C}$ from human platelet cytosol; characterization of its three forms. Biochem. Biophys. Res. Commun. 136:713-721.

27. Gomperts, B. D. 1983. Involvement of guanine nucleotidebinding protein in the gating of $\mathrm{Ca}^{2+}$ by receptors. Nature (Lond.). 306:64-66.

28. Halsam, R. J., and M. M. L. Davidson. 1984. Guanine nucleotides decrease the free $\left[\mathrm{Ca}^{2+}\right]$ required for secretion of serotonin from permeabilized blood platelets: evidence of a role for GTP-binding proteins in platelet activation. FEBS (Fed. Eur. Biochem. Soc.) Lett. 174:90-95.

29. Cockcroft, S., and B. D. Gomperts. 1985. Role of guanine nucleotide binding protein in the activation of polyphosphoinositide phosphodiesterase. Nature (Lond.). 314:534-536.

30. Wallace, M. A., and J. N. Fain. 1985. Guanosine 5'-O-thiotrisphosphate stimulates phospholipase $\mathrm{C}$ activity in plasma membranes of rat hepatocytes. J. Biol. Chem. 260:9527-9530.

31. Uhing, R. J., H. Jiang, V. Prpic, and J. H. Exton. 1985. Regulation of a liver plasma membrane phosphoinositide phosphodiesterase by guanine nucleotides and calcium. FEBS (Fed. Eur. Biochem. Soc.) Lett. 188:317-320.

32. Lucas, D. O., S. M. Bajjalieh, J. A. Kowalchyk, and T. F. J. Martin. 1985. Direct stimulation by thyrothropin-releasing hormone (TRH) of polyphosphoinositide hydrolysis in $\mathrm{GH}_{3}$ cell membranes by a guanine nucleotide modulated mechanism. Biochem. Biophys. Res. Commun. 132:721-728.

33. Gonzalez, R. A., and F. T. Crews. 1985. Guanine nucleotides stimulate production of inositol trisphosphate in rat cortical membranes. Biochem. J. 232:799-804.

34. Smith, C. D., C. C. Cox, and R. Snyderman. 1986. Receptorcoupled activation of phosphoinositide-specific phospholipase $\mathrm{C}$ by an N protein. Science (Lond.). 232:97-100.

35. Smith, C. D., B. C. Lane, I. Kusaka, M. W. Verghese, and R. Snyderman. 1985. Chemoattractant receptor-induced hydrolysis of phosphatidylinositol bisphosphate in human polymorphonuclear leukocyte membranes. J. Biol. Chem. 260:5875-5878.

36. Molski, T. F. P., P. H. Naccache, M. L. Marsh, J. Kermode, E. L. Becker, and R. I. Sha'Af. 1984. Pertussis toxin inhibits the rise in the intracellular concentration of free calcium that is induced by chemotactic factors in rabbit neutrophils: possible role of the $G$ proteins in calcium mobilization. Biochem. Biophys. Res. Commun. 124:644650.

37. Volpi, M., P. H. Naccache, and T. F. P. Molski. 1985. Pertussis toxin inhibits $\mathrm{fMet}$-Leu-Phe but not phorbol ester-stimulated changes in rabbit neutrophils: Role of $\mathrm{G}$ proteins in excitation response coupling. Proc. Natl. Acad. Sci. USA. 82:2708-2712.

38. Okajima, F., and M. Ui. 1984. ADP-ribosylation of the specific membrane protein by islet-activating protein, pertussis toxin, associated with inhibition of a chemotactic peptide-induced arachidonate release in neutrophils. J. Biol. Chem. 259:13863-13871.

39. Bokoch, G. M., and A. G. Gilman. 1984. Inhibition of receptor-mediated release of arachidonic acid by pertussis toxin. Cell. 39:301-308.

40. Bradford, G. P., and R. P. Rubin. 1985. Pertussis toxin inhibits chemotactic factor induced phospholipase $C$ stimulation and lysosomal enzyme secretion in rabbit neutrophils. FEBS (Fed. Eur. Biochem. Soc.) Lett. 183:317-320.

41. Verghese, M. W., C. D. Smith, and R. Snyderman. 1985. Potential role for a guanine nucleotide regulatory protein in chemoattractant receptor-mediated polyphosphoinositide metabolism, $\mathrm{Ca}^{+2}$ mobilization and cellular responses by leukocytes. Biochem. Biophys. Res. Commun. 127:450-457.

42. Lad, P. M., C. V. Olson, and P. A. Smiley. 1985. Association of the N-formyl-Met-Leu-Phe receptor in human neutrophils with a GTP-binding protein sensitive to pertussis toxin. Proc. Natl. Acad. Sci. USA. 82:869-873. 
43. Nakamura, T., and M. Ui. 1985. Simultaneous inhibitions of inositol phospholipid breakdown arachidonic acid release, and histamine secretion in mast cells by islet-activating protein, pertussis toxin. J. Biol. Chem. 260:3584-3593.

44. Brandt, S. J., R. W. Dougherty, E. Lapetina, and J. E. Niedel. 1985. Pertussis toxin inhibits chemotactic peptide-stimulated generation of inositol phosphates and lysosomal enzyme secretion in human leukemic (HL-60) cells. Proc. Natl. Acad. Sci USA. 82:3277-3280.

45. Krause, K. H., W. Schlegel, C. B. Wollheim, T. Andersson, F. A. Waldvogel, and P. D. Lew. 1985. Chemotactic peptide activation of human neutrophils and HL-60 cells. J. Clin. Invest. 76:1348-1354.

46. Okajima, F., T. Katada, and M. Ui. 1985. Coupling of the guanine nucleotide regulatory protein to chemotactic peptide receptors in neutrophil membranes and its uncoupling by islet-activating protein, pertussis toxin. J. Biol. Chem. 260:6761-6765.

47. Undenfriend, S., S. Stein, P. Bohlen, W. Dairman, W. Leimgruber, and M. Weigele. 1972. Fluorescamine: a reagent for assay of amino acids, peptides, proteins and primary amines in the picomole range. Science (Wash. DC). 178:871-872.

48. Meek, J. L. 1986. Inositol bis-, tris-, and tetrakis(phosphate)s: analysis in tissues by HPLC. Proc. Natl. Acad. Sci. USA. 83:41624166.

49. Laemmli, V. K. 1970. Cleavage of structural proteins during the assembly of the head of bacteriophage $\mathrm{T}_{4}$. Nature (Lond.). 227:680-685.

50. Magnaldo, I., H. Talwar, W. B. Anderson, and J. Pouysségur. 1987. Evidence for a GTP-binding protein coupling thrombin receptor to PIP $_{2}$-phospholipase $\mathrm{C}$ in membranes of hamster fibroblasts. FEBS (Fed. Eur. Biochem. Soc.) Lett. 210:6-10.

51. Rittenhouse, S. E., and J. P. Sasson. 1985. Mass changes in myoinositol trisphosphate in human platelets stimulated by thrombin. J. Biol. Chem. 260:8657-8660.

52. Haslam, R., and M. Davidson. 1984. Receptor-induced diacyl- glycerol formation in permeabilized platelets: possible role for a GTPbinding protein. J. Recept. Res. 4:605-629.

53. Litosch, I., C. Wallis, and J. N. Fain. 1985. 5-Hydroxytryptamine stimulates inositol phosphate production in a cell-free system from blowfly salivary glands. J. Biol. Chem. 260:5464-5471.

54. Cockcroft, S. 1986. The dependence on $\mathrm{Ca}^{+2}$ of the guaninenucleotide activated polyphosphoinositide phosphodiesterase in neutrophil plasma membranes. Biochem. J. 240:503-507.

55. Cockcroft, S. 1987. Polyphosphoinositide phosphodiesterase: regulation by a novel guanine nucleotide binding protein, Gp. Trends Biochem. Sci. 12:75-78.

56. Martin, T. F. J., D. O. Lucas, S. M. Bajjalieh, and J. A. Kowalchyk. 1986. Thyrothropin-releasing hormone activates a $\mathrm{Ca}^{2+}$-dependent polyphosphoinositide phosphodiesterase in permeable $\mathrm{GH}_{3}$ cells. J. Biol. Chem. 261:2918-2927.

57. Williamson, J. R. 1986. Role of inositol lipid breakdown in the generation of intracellular signals. Hypertension. 8(II):140-156.

58. Uhing, R. J., V. Prpic, Jiang Hang, and J. H. Exton. 1986. Hormone-stimulated polyphosphoinositide breakdown in rat liver plasma membranes. J. Biol. Chem. 261:2140-2146.

59. Higashida, H., R. A. Streath, W. Klee, and M. Nirenberg. 1986. Bradykinin activated transmembrane signals are coupled via No or $\mathrm{Ni}$ to production of inositol 1,4,5-trisphosphate, a second messenger in NG108-15 neuroblastoma-glioma hybrid cells. Proc. Natl. Acad. Sci. USA. 83:942-946.

60. Deery, W. J., F. Rebeiro-Neto, and J. B. Field. 1987. Multiple isoforms of ADP-ribosylated G-like proteins from mammalian thyroid membranes. Biochem. Biophys. Res. Commun. 144:536-542.

61. Majerus, P. N., T. M. Connolly, H. Deckmyn, T. S. Ross, T. E. Bross, H. Ishii, B. S. Bansal, and D. B. Wilson. 1986. The metabolism of phosphoinositide-derived messengers molecules. Science (Wash. DC). 234:1519-1526. 